\title{
TABU PEREMPUAN DALAM BUDAYA MASYARAKAT BANTEN
}

\author{
Ayatullah Humaeni*
}

\begin{abstract}
The article discusses the phenomenon of women taboos and their meaning for Bantenese women. How Bantenese women understands taboos that exist around them and still transmitted for generations becomes one of main focuses of this article. Besides, it also tries to identify and analyze various kinds of taboo dealing with Bantenese women. This article is the result of a field research using case study method based on anthropological perspective. Library research, participantobservation, and depth-interview are methodes used to collect the data. The existence of women taboos in the Bantenese culture, less or more, influences the socio-religious life of Bantenese women. If we analyze the content and meaning of women taboos based on their socio-cultural context, various tabus existed in Bantenese society, especially dealing with women taboos, possess functions and meaning as a form of maintaing women's moral and behaviours, preserving self-identity and social-identity, strengthening emotional relationships, protecting toward women, and becoming a symbol of love.
\end{abstract}

Key Words: tabu, women, culture, Banten

\begin{abstract}
ABSTRAK
Artikel ini mengkaji fenomena tabu $(t a b u)$ perempuan dan maknanya bagi perempuan Banten. Bagaimana perempuan Banten memahami dan memaknai tabu-tabu yang hadir di sekitar mereka dan masih ditradisikan dari generasi ke generasi menjadi salah satu fokus utama artikel ini. Di samping itu, artikel ini juga mencoba mengidentifikasi dan menganalisis berbagai jenis tabu yang berhubungan dengan perempuan Banten. Artikel ini merupakan hasil penelitian lapangan dengan menggunakan metode study kasus yang bersifat deskriptif kualitatif dengan pendekatan antropologis. Metode yang digunakan untuk mengumpulkan data adalah kajian pustaka, observasi, dan wawancara mendalam. Keberadaan tabu perempuan dalam budaya Banten, sedikit banyak, mempunyai pengaruh bagi kehidupan sosial keagamaan masyarakat Banten. Jika menganalisis isi dan makna tabu berdasarkan kontkes sosial kulturalnya, beragam tabu yang ada pada masyarakat Banten, khususnya yang berkaitan dengan tabu perempuan Banten, memiliki fungsi dan makna sebagai bentuk penjagaan moral dan perilaku, pemeliharaan identitas diri dan identitas sosial, memperkuat hubungan emosional, bentuk perlindungan, sampai simbol kasih sayang dan cinta.
\end{abstract}

Kata Kunci: tabu, perempuan, budaya, Banten

* Dosen Antropologi dan Sosiologi Agama, Fakultas Ushuluddin, Dakwah dan Adab IAIN Sultan Maulana Hasanuddin Banten 


\section{PENGANTAR}

Tabu (tabu) atau pantangan merupakan suatu hal yang hampir selalu ada dalam setiap budaya masyarakat di mana pun, terutama budaya masyarakat primitif. Berbagai penelitian, terutama yang dilakukan oleh orang-orang Barat, menunjukkan betapa tabu-tabu (pantangan/ larangan) hampir selalu muncul dalam berbagai aktivitas sosial keagamaan masyarakat. Dalam melakukan beragam aktivitas sosial mereka, orangorang primitif khususnya, selalu memperhatikan apakah ada tabu berkaitan dengan aktivitas mereka untuk menghindari hal-hal yang mungkin dilarang dalam tabu yang ada dalam budaya mereka. Tabu ini dianggap mengandung pesan-pesan moral bagi masyarakat yang meyakininya sehingga sering kali seseorang yang ingin melakukan sesuatu terpaksa membatalkannya ketika hal itu dianggap bertentangan atau dilarang dalam tabu yang mereka yakini.

Perempuan Banten, khususnya yang tinggal di pedesaan, paling banyak mendapat "pantangan" untuk melakukan aktivitas-aktivitas tertentu yang ditabukan. Sebagian masih percaya dan masih menghindari hal-hal yang ditabukan tersebut meskipun mereka tahu bahwa tabu bukanlah larangan yang berasal dari ajaran agama (Islam), juga bukan tindakan yang dilarang oleh hukum negara. Apa yang mereka ketahui tentang tabu yang ada di sekitar mereka adalah sesuatu yang berasal dari orang tua dan leluhur mereka. Kepercayaan mereka akan kesakralan tabu, bukan pada isi dari tabu itu sendiri, tetetapi lebih kepada "hikmah" yang terkandung dalam kata-kata yang keluar dari orang tua mereka (terutama ibu). Kata-kata tabu ini bagi sebagian perempuan Banten mengandung kebaikan dan sering kali dianggap punya nilai sakral karena hal itu sudah diwariskan dari generasi ke generasi.

Ada banyak aktivitas dan kegiatan yang dilarang atau ditabukan bagi perempuan di Banten. Sejak mereka mengandung, melahirkan, masa bayi, masa anak-anak, masa pubertas, dan masa perkawinan, perempuan di Banten hampir selalu dikelilingi oleh tabu. Terlepas dari keyakinan mereka akan kebenaran dari tabu-tabu tersebut, sebagian masyarakat Banten, khususnya perempuan yang tinggal di pedesaan, masih terus mempraktikkan dan memercayai tabu-tabu tersebut. Tabu yang paling dipercayai dan paling sering dipraktikkan oleh perempuan Banten adalah tabu yang berkaitan dengan kehamilan/ melahirkan. Hal ini barangkali disebabkan oleh kondisi psikologis perempuan hamil/melahirkan yang dikuasai oleh rasa khawatir berlebihan akan kondisi kesehatannya dan yang terpenting kondisi janin dan bayi yang ada dalam kandungan mereka. Karena kondisi cemas dan khawatir semacam itu, perempuan sedapat mungkin menghindari apaapa yang ditabukan oleh adat mereka meskipun barangkali dalam kondisi biasa mereka tidak memercayai kekuatan "mana" dari tabu-tabu tersebut.

Perempuan hamil di Banten adalah objek yang paling banyak dikenai tabu-tabu. Terdapat berbagai pantangan yang harus dihindari oleh mereka jika mereka ingin ia dan bayinya selamat dan tidak mengalami kesulitan dalam melahirkan atau anaknya akan cacat. Di antara tabu-tabu yang harus dihindari oleh ibu-ibu hamil di daerah Banten adalah wong meteng mah ora olih ngumbah sikil kalawan banyu bekas kumbahan, matak ngalahirakene gati 'perempuan hamil tidak boleh mencuci kaki dengan air bekas cucian, takut susah melahirkan'; wong meteng mah ora olih mangan karo piring gede, matak bayine gati metune perempuan hamil tidak boleh makan menggunakan piring besar, takut nanti susah melahirkan'; wong meteng mah ora olih mateni sasatoan, matak anake cacat 'perempuan hamil tidak boleh membunuh hewan apa pun, takut anaknya lahir cacat'; dan lain sebagainya (Juju, 2014).

Perempuan yang melahirkan atau pasca melahirkan juga memiliki banyak pantangan (tabu). Ibu-ibu yang baru saja melahirkan paling sering diingatkan oleh orang-orang tua untuk tidak melakukan aktivitas tertentu, seperti wong entas ngalahiraken mah ora olih mangan gedang, matak metu kontol 'perempuan yang habis melahirkan tidak boleh makan pisang, takut keluar penis'; wong wadon sing entas lahiran ora ulih dodok slonjor ning arep umah matak diintili setan 'perempuan yang habis melahirkan tidak boleh duduk slonjoran di depan rumah, takut diikuti setan'; wong wadon tas lahiran ora olih mangan lele, matak pendarahan 'perempuan habis melahirkan tidak boleh makan ikan lele, takut 
mengalami pendarahan'; dan lain sebagainya. (Een, 2014).

Artikel ini merupakan hasil penelitian lapangan yang mencoba menggali berbagai tabu perempuan Banten yang masih tersebar di berbagai wilayah Banten, dan masih diyakini dan ditradisikan oleh banyak perempuan Banten, baik yang tinggal di pedesaan maupun di perkotaaan. Pemahaman para perempuan Banten terkait berbagai tabu yang masih terekam dalam memori kolektif mereka dan juga masih diwariskan kepada keturunan mereka menjadi sasaran utama dari penelitian ini.

Penelitian ini akan menggunakan metode studi kasus yang bersifat deskriptif kualitatif dengan menggunakan pendekatan antropologis. Menurut Stake, studi kasus adalah pilihan terhadap objek penelitian, bukan konsekuensi metodologis. Kasus-kasus yang dipilih mungkin bersifat sederhana, mungkin juga rumit dan kompleks (Stake, 2009:299). Dalam hal ini, Nyoman Kutha Ratna menyatakan bahwa "secara definitif studi kasus mensyaratkan sebuah penelitian dengan kekhasan tertentu, unik. Dalam hubungan ini, peneliti sudah memiliki pandangan bahwa di lokasi yang bersangkutan ada suatu masalah yang berbeda, bahkan mungkin menyimpang" (Ratna, 2010: 190-192).

Metode pengumpulan data menggunakan kajian pustaka, pengamatan, dan wawancara. Analisis data mencakup analisis selama pengumpulan data, reduksi data sebagai proses pemilihan, pemusatan perhatian pada penyederhanaan, pengabstrakan, transformasi data kasar yang muncul dari catatan-catatan lapangan, penyajian data, dan penarikan kesimpulan/ verifikasi. Analisis data bersifat induktif-kualitatif.

Kajian tentang tabu, baik secara teoretis maupun praktiknya dalam berbagai budaya masyarakat di berbagai belahan dunia dapat ditemukan dalam beberapa referensi yang ditulis oleh para ahli antropologi dan sosiologi. Webster (1942) dalam karyanya Taboo: A Sociological Theory membahas teori tabu secara komprehensif. Dalam karyanya ini, Webster menjelaskan secara detail sifat alamiah dari tabu, sangsi sosial bagi pelanggar tabu, berbagai tabu dalam siklus kehidupan manusia, terutama dalam hal yang berkaitan dengan kehidupan reproduksi perempuan seperti tabu menstruasi, tabu perempuan hamil, dan tabu perempuan melahirkan. Tabu-tabu yang berkaitan dengan kehidupan seksual dan tentang kematian juga dijelaskan secara komprehensif dalam karya Webster ini.

Frazer, seorang antropolog, dalam karyanya yang terkenal The Golden Bough: A Study in Magic and Religion, juga banyak menjelaskan berbagai jenis tabu di berbagai belahan dunia. Karya besar Frazer yang terdiri dari 12 volume ini menjadi buku rujukan penting bagi siapa pun yang mengkaji tentang agama primitive, tentang beragam praktek magis pada masyarakat primitive, dan berbagai hal yang berkaitan dengan perilaku keberagamaan masyarakat primitif di berbagai belahan dunia. Dari 12 volume karya besarnya ini, hampir lebih dari 50\% membahas beragam tabu-tabu yang ada pada berbagai masyarakat di berbagai belahan dunia, termasuk di dalamnya sedikit membahas tabu-tabu pada masyarakat Melayu (Frazer, 1993). Selanjutnya, Malinowski dalam karyanya Magic, Science and Religion juga di beberapa bagian dari karyanya ini membahas praktik tabu di kepulauan Trobriand, di tempat dia melakukan penelitian ethnografi (Malinowsky, 1955).

Freud dalam karyanya Totem and Taboo membahas totem dan tabu dengan pendekatan psikoanalisis. Freud berpendapat bahwa tabu berasal dari bahasa Polinesia yang bermakna prohibition (pantangan/larangan) atau restriction (batasan). Antonim tabu dalam bahasa Polinesia ini adalah noa yang bermakna sesuatu yang biasa dan umumnya dapat diakses. Freud juga berpendapat larangan-larangan tabu semuanya tidak punya dasar pembenaran dan asal-usulnya tidak diketahui. Pembatasan-pembatasan tabu berbeda dengan larangan-larangan agama atau moral (Freud, 1950:30-31). Tabu berbeda dengan larangan agama karena tabu-tabu ini tidak terlacak pada firman Tuhan atau wahyu Tuhan seperti yang tertera dalam kitab-kitab-Nya, tetapi pembatasanpembatasan tabu itu sendiri betul-betul ada dan memaksakan dirinya sendiri untuk menjadi tabu. Larangan-larangan yang ada dalam tabu juga berbeda dengan larangan-larangan moral dengan alasan karena gagalnya tabu dimasukan dalam sebuah sistem yang menerangkan pantangan atau penahan nafsu secara umum yang diperlukan oleh orang-orang dan ada alasan untuk kebutuhan akan 
tabu ini (Freud, 1950:31). Meskipun tidak dapat dipahami secara logis, tabu-tabu ini diterima sebagai suatu hal yang perlu dipatuhi dan tidak boleh dilanggar oleh orang-orang yang pikirannya didominasi oleh label tabu ini.

Berdasarkan latar belakang di atas, artikel ini mencoba menemukan jawaban atas permasalahan (1) bagaimana perempuan Banten memahami dan memaknai tabu dalam kehidupan mereka; (2) tabu apa saja yang masih tersebar dan masih diwariskan oleh perempuan Banten; dan (3) apa fungsi tabu bagi perempuan Banten?

\section{TEORI TENTANG TABU}

Dari beberapa karya tentang tabu yang ditulis oleh para ahli di atas, tabu umumnya didefinisikan sebagai sebuah larangan atau pantangan. Kata ini berasal dari kata Polinesia tapu. Ide tentang tabu sangat tersebar luas dalam budaya-budaya manusia dan dalam sistem-sistem agama termasuk agama "langit" dan agama dunia yang sering kali dihubungkan dengan ide-ide kesakralan atau kesucian juga sering kali dikaitkan dengan ideide tentang kata-kata tidak senonoh (kotor) atau najis (Hamilton, 2001:141; Freud, 1950; Gell, 2002:290-305).

Banyak istilah yang digunakan pada sebagian masyarakat lain yang memiliki beragam bahasa yang sebenarnya merujuk pada makna atau definisi yang sama dengan istilah tabu, seperti tapu atau taboo dalam bahasa Polinesia, tafoo pada masyarakat Sandwich Islands, sacer dalam bahasa Romawi Kuno, ayos dalam bahasa Yunani, kodaush dalam bahasa Hebrew, tabu atau pantangan dalam bahasa Indonesia, pamali dalam bahasa Sunda Banten, dan barangkali masih banyak istilah lain yang digunakan di berbagai daerah (Freud, 1950:21; Gell, 2002:290-305; Humaeni, 2010:25).

Freud berpendapat bahwa tabu berasal dari bahasa Polinesia yang bermakna 'pantangan/ larangan' (prohibition) atau 'batasan' (restriction). Antonim tabu dalam bahasa Polinesia ini adalah noa yang bermakna sesuatu yang biasa dan umumnya dapat diakses (Freud, 1950:30; Bowen, 1998:127-128). Dalam Dictionary of Religious, Hinnels memberikan definisi yang kurang lebih sama dengan definisi Freud, yaitu a restriction or ban on potent and sacred things (Hinnels, 1984:319).
Menurut Northcote W.Thomas dalam Encyclopedia Britannica, sebagaimana dikutip oleh Freud, tabu memiliki banyak tujuan, yaitu (1) melindungi orang-orang penting, seperti kepala-kepala suku, kepala-kepala adat, pemimpin masyarakat, dan sebagainya; (2) melindungi orangorang yang dianggap lemah, seperti perempuan, anak-anak, dan orang-orang awam pada umumnya dari kekuatan "mana" atau pengaruh magic; (3) memberikan penjagaan atas bahaya yang terjadi karena menangani atau melakukan kontak dengan mayat karena memakan makanan tertentu, dan sebaginya; (4) menjaga aktivitas-aktfitas para kepala suku, seperti dalam proses kelahiran, proses inisiasi, pernikahan, dan hubungan seksual; (5) menjaga manusia dari kemurkaan dan kemarahan dewa dan ruh-ruh; dan (6)mengamankan bayi-bayi yang baru lahir dan anak-anak kecil yang memilki hubungan simpatetik dengan orang tuanya. Tabu juga diadakan untuk mengamankan masyarakat dari para pencuri yang akan mengambil harta bendanya (Freud, 1950:31-33).

Dari beberapa penafsiran tentang tabu di atas, dapat disimpulkan bahwa tabu hampir selalu mengandung pesan atau nilai moral yang harus dijaga dan dilestarikan oleh masyarakat agar mereka dapat mengontrol tindakan dan sikap mereka supaya sesuai dengan budaya dan moral masyarakat setempat. Selanjutnya, sebagaimana pernyataan Thomas di atas, tampak bahwa ia memandang perempuan sebagai salah satu mahluk yang lemah sehingga perlu dijaga dari bahaya dan kesulitan, terutama yang ditimbulkan oleh roh-roh jahat atau pun dari black magic melalui beragam tabu. Namun demikian, ada juga yang berpendapat bahwa banyaknya tabu yang cenderung mendeskreditkan perempuan dan menguntungkan laki-laki. Tabu tampaknya dipandang sebagai simbol otoritas laki-laki atas diri perempuan sehingga dalam berbagai aktivitas sosial-keagamaan perempuan dibatasi oleh pantangan-pantangan untuk membatasi aktivitas perempuan dalam kehidupan sosial yang banyak didominasi oleh laki-laki (Handayani dan Sugiarti, 2002:11-12). 


\section{TABU PEREMPUAN DI BERBAGAI SUKU BANGSA}

Traneman (2010:233) menyatakan bahwa

"perempuan ... tidak pernah diberitahu apa-apa tentang menstruasi sehingga berpikir akan mati karena berdarah, ketika pertama kali mengalami menstruasi. Atau sudah pernah diberitahu tentang menstruasi sebelumnya oleh kawan di sekolah sambil cekikikan dan mengatakan bahwa menstruasi itu kotor. Atau sudah dipersiapkan oleh ibu mereka, yang dengan hati-hati menjelaskan bahwa menstruasi tidak kotor, tetetapi pembicaraan tersebut dilakukan dengan berbisik dan menunjukkan seakan menstruasi adalah 'kutukan' ..."

Traneman (2010:233) juga berpendapat sebagai berikut.

"Kesan akan rasa malu tentang menstruasi disisipkan segera setelah menstruasi itu dimulai. Sejak awal mengalami menstruasi, anak perempuan belajar untuk menjadi malu akan tubuh mereka sendiri; ia diberitahu bahwa menstruasi membatasi kebebasannya, karena fungsi alamiahnya... kalau ada celah tak berisi [pada pendidikan], maka akan banyak cerita rakyat yang menambalnya: 'sembunyikan menstruasi, jangan berenang, cuci rambut, mandi, atau menyentuh tanaman ...' ini adalah beberapa rumor yang dibisikkan kepada anak perempuan. Bagaiman mereka dapat belajar untuk berbangga hati menjadi perempuan?"

Dua kutipan di atas menunjukkan bagaimana kondisi perempuan dikonstruk sedemikian rupa oleh struktur sosial dan budaya masyarakat untuk selalu berada dalam batasan-batasan dan dikekang kebebasannya untuk melakukan banyak hal karena sifat alamiah perempuan. Konstruk semacam ini terus dipertahankan dalam banyak budaya manusia sepanjang sejarah, bahkan mungkin sampai saat ini, perempuan hampir selalu jadi golongan manusia kelas dua karena kodrat perempuan yang dapat mengalami masa menstruasi dan melahirkan dianggap sebagai kelemahan perempuan. Wacana semacam ini terus bertahan dalam berbagai tradisi dan budaya manusia sepanjang sejarah manusia
(Webster, 1942:110-112; Ornstein, 1994:51-66).

Dalam berbagai literatur antropologi dan dalam catatan-catatan etnografi para peneliti Barat, dapat disaksikan bagaimana posisi perempuan dalam komunitas atau dalam suku-suku masyarakat primitif. Perempuan diperlakukan sebagai manusia golongan kedua dan selalu di bawah kontrol dan dominasi laki-laki. Pada masa-masa tertentu, seperti dalam kondisi menstruasi, beragam tabu dibentuk untuk membatasi dan menghalangi aktivitas perempuan. Kondisi yang dibentuk oleh budaya patriarki ini membuat perempuan selalu berada dalam posisi subordinat dan tidak pernah diberi kesempatan untuk mengubah apa yang sudah menjadi hukum adat atau tradisi masyarakat setempat, betapapun kondisi ini selalu menjadikan perempuan sebagai korban (Webster, 1942:110; Frazer, 1935:213-222).

Bahkan, negara-negara Barat sendiri, sebelum masa pencerahan, juga memperlakukan dan memposisikan perempuan sebagai manusia kelas kedua yang segala aktivitasnya dibatasi oleh berbagai macam larangan dan undangundang. Di dalam masyarakat Barat, menurut Turner, agama Kristen secara historis menjadi perangkat paling penting dalam mengontrol tubuh perempuan, oleh karenanya gerakan emansipasi perempuan sebenarnya adalah perjuangan melawan konseptualisasi agama terhadap seksualitas. Di dalam agama Katolik Eropa, Gereja masih dipandang sebagai bagian terpenting lembaga kegaamaan publik yang dengannya perempuan ditempatkan pada posisi sosial yang tersubordinasi (Turner, 2003:404).

Tempat-tempat pengucilan dan pengasingan bagi perempuan yang sedang menstruasi hampir selalu ada di negara-negara Barat pada masa sebelum zaman pencerahan. Tempat-tempat ini menjadi sebuah tempat pemasungan atas hak-hak perempuan yang sedang menstruasi karena mereka dianggap kotor dan tabu untuk berhubungan/bersentuhan dengannya. Ketakutanketakutan dan kekhawatiran-kekhawatiran akan pengaruh buruk "mana" yang ada pada perempuan menstruasi ini dikonstruk sedemikian rupa untuk membatasi gerak dan aktivitas perempuan, dan perempuan hampir selalu menjadi objek penderita bagi dominasi dan hegemony laki-laki. Bentuk penindasan semacam ini terus bertahan di Barat 
sampai datangnya gerakan emansipasi perempuan dan gerakan feminis (Turner, 2003:404-405).

Nur Syam berpendapat bahwa subordinasi perempuan yang menempatkan perempuan pada posisi subordinat di berbagai bidang kehidupan bukan hanya dikonstruk oleh kondisi sosial, budaya, struktur sosial, dan sikap patriarki politik, tetapi juga oleh unsur religi (Syam, 2010:34). Kekotoran perempuan pada masa-masa tertentu dari kehidupan reproduksi mereka nampaknya menjadi hal yang paling bertanggung jawab atas tersebar luasnya ide-ide tentang kekotoran permanen mereka dan bahwa pada gilirannya, ide itu menjelaskan pemaksaan beragam tabu yang di desain untuk mencegah kontak seksual atau meminimalisir bahaya yang dipercaya dapat terjadi karena adanya kontak tersebut. Tabu-tabu tersebut sangat memberatkan masyarakat primitif dan membatasi gerak mereka dalam beragam aktivitas, baik aktivitas sosial biasa maupun aktivitas keagamaan (Webster, 1942:110; Frazer, 1935:213222; Laws, 1990; Buckley and Gottlieb, 1988:7).

Kajian tentang berbagai tabu pada berbagai suku primitif di banyak negara di dunia memperlihatkan betapa perempuan menjadi golongan manusia kelas kedua yang betul-betul dibebani dan dikekang dengan berbagai tabu. Di pulau Meli, salah satu dari pulau New Hibrides, misalnya, laki-laki menyiapkan sumua makanan mereka di dalam rumah perkumpulan (rumah bola) mereka, perempuan dilarang mendatangi tempat itu. Mereka melakukan itu karena ada kepercayaan mereka yang menganggap apa pun yang dimasak oleh perempuan itu kotor/najis bagi laki-laki. Selanjutnya, beberapa kepala suku Samoan dari golongan kelas bawah membolehkan perempuan makan bersama-sama dengan mereka, tetapi secara umum, perempuan dan anak-anak tidak boleh makan bersama mereka. Di pulau Marquesas, berlaku aturan bahwa seorang istri tidak boleh makan di tempat yang sama dengan suaminya dan tidak boleh masak di tungku laki-laki. Jika mereka melanggarnya, perempuan akan dibunuh dan disiksa. Namun, kadang-kadang hukuman mereka diserahkan kepada ruh-ruh jahat yang dapat membuat perempuan jadi sakit. Menurut catatan awal seorang pengunjung yang datang ke pulau Hawai, di dalam rumah perempuan-perempuan di pulau ini dilarang makan bersama-sama dengan laki-laki, bahkan dilarang untuk memasuki ruang makan ketika laki-laki sedang makan. Pada suku Indian Amerika juga terdapat banyak bukti catatan yang menyatakan bahwa perempuan tidak makan bersama laki-laki, sampai semua laki-laki dirumahnya sudah makan dengan puas (Webster, 1942:111-112).

Dalam hal pekerjaan, dalam masyarakat primitif, ada banyak pekerjaan yang boleh dilakukan oleh laki-laki, tetapi dilarang (tabu) untuk perempuan. Perempuan di pulau Hawai, misalnya, tidak diperbolehkan terlibat dalam pekerjaan pertanian atau dalam aktivitas memancing. Di antara beberapa suku di Afrika Selatan yang menggunakan bahasa Bantu, perempuan juga dilarang menjaga dan memelihara sapi perah dan bekerja di perusahaan susu. Bahkan prempuan tidak pernah diperbolehkan menyentuh binatang itu. Jika mereka melanggarnya, mereka akan disiksa dengan pukulan (Webster, 1942:113-114).

Tampaknya, tabu yang diberlakukan kepada perempuan di berbagai suku bangsa sebagaimana dijelaskan di atas disebabkan oleh satu keyakinan dan pemahaman yang sudah dikonstruk sedemikian rupa oleh sistem budaya yang ditanamkan dan dibentuk selama ratusan tahun demi mempertahankan kekuasaan dan superioritas laki-laki. Penafsiran agama tampaknya juga mengambil bagian dalam memosisikan perempuan sebagai golongan inferior.

\section{TABU PEREMPUAN DAN SIMBOL HEGEMONI}

Weber berpendapat bahwa tabu ada dan berkembang untuk kepentingan ekonomi, politik, status, prestise, dan privilege dari seseorang atau golongan tertentu, oleh karenanya tabu-tabu ini dibiarkan ada dan dipercayai oleh masyarakat agar mereka dapat mempertahankan kepentingan dan otoritas mereka di masyarakat (Weber, 1964:3739). Sebagai contoh, rakyat biasa tabu kalau menyentuh benda-benda yang dimiliki oleh raja atau pimpinan mereka atau memakan sesuatu yang dimakan oleh raja atau pimpinan mereka karena banyak hal yang dimiliki oleh raja atau para pimpinan dilabeli tabu bagi rakyat biasa. Pelanggaran atas tabu ini tentu akan berpengaruh buruk atau membawa konsekwensi bagi rakyat yang melanggarnya. Ini jelas bahwa para raja, 
kepala suku atau pemimpin rakyat, dan para bangsawan sengaja membiarkan diri mereka dilabeli sebagai tabu untuk dapat mempertahankan status dan prestise mereka di mata rakyat.

Bagaimana dengan tabu-tabu untuk perempuan (women taboo)? Kalau dilihat dalam konteks sejarah bagaimana perempuan diperlakukan semena-mena, semata-mata karena ia terlahir sebagai perempuan yang punya sifat alamiah dan secara biologis dapat mengeluarkan darah menstruasi setiap bulannya bagi yang sudah pubertas. Darah yang keluar dari perempuan yang sedang menstruasi dianggap sebagai darah kotor dan najis yang mengandung magi jahat dan dapat membawa pengaruh buruk bagi orang-orang di sekitarnya. Karena anggapan dan kepercayaan yang terus diwariskan dari generasi ke generasi, perempuan menjadi korban atas wacana yang dimitoskan oleh si pembuat tabu dan didukung oleh mayoritas masyarakat, bahkan oleh perempuan itu sendiri sebagai korban. Sering kali perempuan sendirilah (ibu, kakak perempuan, bibi, atau nenek) yang menjejali anak-anak mereka dengan kekotoran darah menstruasi. Tradisi ini terbentuk sedemikian kuat tanpa perlawanan karena dipercayai dan didukung oleh hampir semua elemen masyarakat, termasuk perempuan (Ornstein, 1994; Webster, 1942; Gell, 2002).

Pada masa-masa kegelapan itu, perempuan terpaksa harus mengalami penderitaan panjang karena kodrat mereka sebagai perempuan. Berbagai tempat/rumah pengucilan untuk wanitawanita yang sedang menstruasi dibuat di berbagai tempat. Perempuan harus menerima dengan pasrah dengan dogma tabu yang sebenarnya diciptakan untuk mengekang kebebasan dan aktivitas mereka. Banyak hal dilarang atau ditabukan bagi perempuanperempuan menstruasi. Mereka tidak boleh makan makanan tertentu, tidak boleh melakukan berbagai aktivitas di depan publik, tidak boleh berhubungan badan dengan suami-suami mereka, tidak boleh melakukan kontak dengan orang lain, bahkan dengan anggota keluarga mereka sendiri. Perempuan-perempuan menstruasi ditempatkan di tempat-tempat pengasingan yang sepi, pengap, dan kotor. Tidak boleh ada satupun anggota keluarga yang menjenguknya, apalagi bersentuhan dengan mereka. Jika semua itu dilanggar, bukan hanya perempuan menstruasi itu saja yang akan menerima kutukan atau pengaruh magi jahat, tetetapi juga orang yang melakukan kontak dengannya, bahkan seluruh anggota keluarga dan masyarakat (Callois, 1959; Durkheim, 1995; Freud, 1950).

Berbagai tabu yang sengaja diciptakan oleh masyarakat primitif dan masyarakat Barat sebelum zaman pencerahan itu tentu bukan kosong makna. Ada segelintir atau sekelompok orang yang sengaja menciptakan tabu-tabu tersebut dengan kepentingan-kepentingan tertentu. Ada kecemasan dan kekhawatiran pada si pembuat tabu akan pengaruh perempuan yang mungkin dapat melampaui kekuatan, posisi, dan prestisenya di mata masyarakat. Barangkali, mereka (si pembuat tabu) melihat adanya power yang luar biasa dalam diri perempuan yang jika tidak dibatasi akan merusak tatanan sosial dan hegemoni yang selama ini sudah mereka bangun. Ketakutan dan beban psikologis akan kehilangan power dan kedudukan sosial di mata masyarakat membuat mereka melakukan upaya halus untuk mengeliminasi dan menyingkirkan kemungkinan-kemungkinan terburuk bangunnya kesadaran perempuan akan ketertindasan yang selama ini dibangun oleh sekelompok orang demi mempertahankan status quo. Jika demikian, mungkinkah laki-laki yang paling bertanggung jawab atas penderitaan dan siksaan panjang yang dialami kaum perempuan?

Kalau membaca berbagai literatur tentang masyarakat suku primitif dan sejarah Eropa masa kegelapan, dapat dilihat bagaimana hegemoni lakilaki atas tubuh perempuan. Kontrol yang sangat ketat atas perempuan-perempuan yang sedang menstruasi melalui penciptaan beragam tabu dan juga hukuman bagi para pelanggar tabu, serta berbagai tempat/rumah pengucilan yang dibuat untuk perempuan menstruasi mengindikasikan bahwa perempuan dianggap sebagai manusia kelas kedua yang harus selalu tunduk pada kekuasaan dan kontrol laki-laki. Perempuan dianggap tidak layak untuk melakukan berbagai aktivitas publik sebagaimana dilakukan oleh laki-laki. Perempuan hanya diberi tugas untuk mengurus urusan rumah tangga dan mengurus anak dan suami. Mereka tidak boleh terlibat aktif dalam berabgai aktivitas sosial, apalagi dalam urusan politik. Aib bagi perempuan pada masa itu untuk berpartisipasi dalam aktivitas dan kegiatan yang biasa dilakukan oleh lakilaki. Kondisi semacam ini terus dipertahankan atas kontrol laki-laki, baik sebagai kepala rumah 
tangga, kepala suku, maupun pemimpin dari sebuah negara.

Bagaimana dengan tabu perempuan di Banten? Apakah keberadaan tabu-tabu itu melambangkan adanya hegemoni laki-laki atas perempuan Banten? Jika melihat hasil dari data lapangan baik melalui observasi dan interview, tidak terlihat kecendurungan adanya hegemoni laki-laki atas perempuan Banten. Tabu perempuan Banten bukanlah simbol atas kekuasaan laki-laki terhadap perempuan. Makna yang terkandung dalam tabu-tabu perempuan Banten lebih pada perlindungan laki-laki atas perempuan Banten. Perlindungan yang dimaksud di sini bukan karena laki-laki Banten menganggap perempuan Banten sebagai makhluk yang lemah dan punya banyak kekurangan sehingga perlu perlindungan extra dari laki-laki sebagaimana yang dijelaskan oleh Thomas dalam Encylopedia Britanica sebagaimana dikutip oleh Freud (1950:31-33), tetetapi lebih pada bentuk kasih sayang laki-laki atas diri perempuan sebagai bagian dari hidupnya, entah itu sebagai anak, istri, atau orang tua.

Fakta bahwa tidak ada makna simbolis dari tabu perempuan Banten yang cenderung ke arah hegemoni laki-laki atas perempuan dapat dilihat dari beberapa indikasi. Pertama, tabu-tabu yang masih dipercayai dan dipraktikkan oleh sebagian perempuan Banten tidak berada pada kontrol lakilaki, dalam hal ini justru sering kali laki-laki tidak paham dan tidak mengetahui hal apa saja yang dilarang dan menjadi pantangan bagi perempuan. Kalaupun kemudian perempuan Banten melanggar tabu yang menjadi pantangan buat mereka, lakilaki tidak pernah menunjukkan sikap marah atau bahkan mengucilkan mereka. Tidak ada lakilaki di Banten yang memarahi atau memukuli istri, anak perempuan, atau ibunya yang sedang menstruasi karena menyentuh barang-barangnya atau menyentuh fisiknya sebagaimana terjadi pada masyarakat primitif atau orang-orang Barat sebelum masa pencerahan. Kalaupun laki-laki tidak menggauli istrinya pada saat menstruasi itu lebih karena adanya dogma atau ajaran agama yang mengharamkan laki-laki menggauli istrinya pada saat menstruasi, bukan karena kekhawatiran adanya pengaruh magi jahat pada istri yang sedang menstruasi. Kedua, perempuan Banten yang sedang menstruasi maupun hamil juga tidak dibatasi gerak dan aktivitasnya dalam kegiatan sosial politik oleh laki-laki; mereka dapat melakukan aktivitas apapun selama perempuan sendiri merasa mampu dan kuat secara fisik untuk melakukan aktivitas itu. Ketiga, dalam berbagai catatan sejarah di Banten tidak terdapat data dan informasi mengenai tempat/rumah pengasingan/ pengucilan bagi perempuan-perempuan yang sedang menstruasi karena mereka menganggap bahwa menstruasi bukanlah sesuatu yang tidak wajar, tetetapi itu adalah sifat alamiah dan kodrat perempuan yang secara biologis harus mengalami masa itu selama mereka belum menginjak masa monopouse. Bahkan, di Banten tidak ada jejak arkeologis yang menandakan adanya tempat/ rumah pengasingan bagi perempuan yang sedang menstruasi.

\section{CARA PEREMPUAN BANTEN MEMAHAMI DAN MEMAKNAI TABU}

Berbagai tabu yang tersebar di Banten banyak yang berkaitan dengan perempuan dan anak-anak, khususnya perempuan hamil dan calon bayinya. Pantangan dan larangan yang diberlakukan bagi perempuan dan anak ini, jika diperhatikan maknanya, sebagian tampak sebagai bentuk perlindungan terhadap perempuan dan anak-anak. Dalam hal ini, Ibu Adl, seorang dukun beranak/ dukun bayi, berpendapat bahwa

"sebenarnya, kalau kita perhatikan, pantangan dan larangan buat perempuan, terutama ibu hamil, itu buat melindungi perempuan dan bayinya. Ibu hamil itu kan kondisinya lemah, jadi butuh perlindungan lebih. Misalnya, ibu hamil tidak boleh mengikatkan handuk di leher, takut pas lahir bayinya kesangkut ari-arinya dan susah lahirannya. Larangan ini sebenarnya secara akal juga benar. Karena perempuan hamil itu kan sering kali susah buat bernafas, jadi kalau dia mengikatkan handuk di leher, kemudian jatuh kan bahaya buat dia dan calon bayinya." (2014).

Dari penuturan tersebut, tampak bahwa sebagian masyarakat Banten memandang bahwa tabu hadir sebagai bentuk perlindungan bagi kaum perempuan dan bayi atau anaknya yang dianggap sebagai makhluk yang lemah. 
Namun demikian, tidak semua berpandangan sama seperti Ibu Adl tersebut di atas. Sebagian perempuan Banten, terutama perempuan yang kuliah atau bekerja di kota atau di tempat lain, berpendapat bahwa keberadaan tabu atau pantangan itu sudah tidak relevan lagi dengan kondisi masa sekarang. Dalam hal ini, Ibu Fzh, seorang mahasiswi di sebuah perguruan tinggi di Kota Serang Banten, misalnya bertutur sebagai berikut.

"Saya merasa tabu itu tidak lagi relevan dengan masyarakat modern. Tabu itu hanya relevan untuk orang-orang tua dan leluhur kita dulu, karena dulu mereka tidak sekolah, belum ada listrik, kerjanya hanya di sawah atau di kebun. Wajar kalau mereka percaya dengan tabu. Saya sendiri termasuk yang kurang percaya dengan tabu dan konsekuensinya. Itu kan membatasi kita, terutama perempuan, untuk beraktivitas, sekolah, atau bekerja. Masa laki-laki saja yang boleh kerja sampai malam. Makanya saya ga begitu peduli dengan berbagai pantangan itu. Toh saya baik-baik saja. Saya yakin kok, kalau kita tidak berbuat maksiat, Allah pasti melindungi. Ga bakalan kita celaka hanya gara-gara melanggar pantangan dan larangan itu." (2014)

Hal senada diungkapkan juga oleh Ibu Yyh, seorang PNS di Kota Serang Banten yang menganggap tabu sebagai bagian dari tradisi lisan nenek moyang yang sudah tidak ada relevansinya dengan zaman sekarang. Apa yang dituturkan oleh Ibu Fzh dan Ibu Yyh adalah gambaran dari perempuan modern yang merasa kebebasannya dibatasi oleh norma adat dan budaya lokal yang dianggap sudah tidak lagi relevan bagi masyarakat modern. Namun demikian, apa yang dituturkan oleh keduanya hanya mewakili sebagian kecil perempuan Banten yang memang sebagian mereka memiliki pendidikan tinggi dan memiliki pengalaman dan wawasan lebih banyak.

Perempuan Banten, khususnya yang tinggal di pedesaan, sebagian masih percaya dan masih menghindari hal-hal yang ditabukan meskipun mereka tahu bahwa tabu bukanlah larangan yang berasal dari ajaran agama (Islam), juga bukan tindakan yang dilarang oleh hukum negara. Apa yang mereka ketahui tentang tabu yang ada di sekitar mereka adalah sesuatu yang berasal dari orang tua dan leluhur mereka. Kepercayaan mereka akan kesakralan tabu, bukan pada isi dari tabu itu sendiri, tetapi lebih kepada "hikmah" atau pelajaranyang terkandung dalam kata-kata yang keluar dari orang tua mereka (terutama ibu). Katakata "tabu" ini bagi sebagian perempuan Banten mengandung kebaikan dan sering kali dianggap punya nilai sakral karena hal itu sudah diwariskan dari generasi ke generasi.

Perempuan-perempuan Banten sebagian besar memahami dan mengetahui bahwa laranganlarangan tabu yang selama ini masih mereka praktikkan tidak didukung oleh teks-teks agama (Islam); mereka juga paham bahwa mengikuti tradisi dan budaya yang tidak terdapat dalam teks agama dianggap bid'ah (sesuatu yang tidak ada hukumnya dalam ajaran Islam) dan mungkin dapat mengarah pada kemusyrikan (menyekutukan Tuhan). Namun demikian, sebagian dari perempuan Banten tetap yakin dan khawatir untuk melanggar tabu karena ada satu dua dari tetangga atau teman mereka atau bahkan mereka sendiri pernah mengalami musibah atau nasib yang kurang baik karena melanggar tabu. Hal serupa juga terjadi pada masyarakat Purbalingga dan Banyumas, yaitu meskipun masyarakat secara lisan sering kali tidak percaya dengan tabu nikah, tetetapi hati mereka sering kali tersugesti oleh tabu tersebut sehingga mereka berada pada posisi ragu antara percaya dan tidak. Namun demikian, pada akhirnya perlahanlahan dan tanpa disadari mereka juga cenderung percaya kepada tabu tersebut (Priyadi, 2006:166).

\section{JENIS-JENIS TABU PEREMPUAN DI BANTEN}

Berdasarkan data lapangan yang dihimpun dari hasil observasi dan interview dari ratusan perempuan Banten, khususnya gadis, ibu-ibu, dan perempuan-perempuan lanjut usia di daerah Banten, tabu untuk perempuan Banten dapat dikategorikan menjadi enam jenis. Pertama, tabu untuk gadis/perawan. Perempuan yang masih gadis atau perawan sering kali dilarang atau tabu melakukan beberapa aktivitas tertentu, seperti perawan aja nyicipi panganan/minuman engkone bokan di icipi wong lanang 'gadis perawan tidak boleh mencicipi makanan/minuman, nantinya 
dicicip (disentuh/disetubuhi) oleh laki-laki'; perawan ora lih nyukur alis bokan ngadeleng setan; dan lain sebagainya.

Kedua, tabu menstruasi. Dalam kondisi menstruasi, perempuan dilarang atau tabu melakukan aktivitas-aktivitas tertentu, misalnya wong haid mah ora olih ngabuang softext/ pembalut asal bae, kudu dibersihaken dikit getihe, matak disedot setan dadi edan atawa gering bae 'perempuan sedang menstruasi tidak boleh membuang pembalut semabarangan, takut darah menstruasinya dihisap setan, nanti jadi gila atau sakit-sakitan', dan sebagainya.

Ketiga, tabu pernikahan. Orang yang akan atau sedang menikah juga dibatasi aktivitasnya oleh tabu-tabu, seperti wong arep dikawinaken mah ora olih metu-metu, matak bilai atawa digawa setan 'perempaun yang mau nikah tidak boleh keluar rumah, takut di bawa setan'; wong arep dikawinaken mah aja adus pas dina kawine, endah pangling kadelenge 'perempuan yang mau menikah tidak boleh mandi, supaya terlihat menarik dan cantik'; aja kawin karo sadulur, matak anake bloon 'jangan menikah dengan orang yang masih ada tali persaudaraan, takut nanti anaknya bodoh-bodoh'; dan sebagainya.

Keempat, tabu perempuan hamil. Tabu nikah nampaknya bukan hanya terjadi di masyarakat Banten. Masyarakat Purbalingga dan Banyumas ternyata juga memiliki tabu sejenis. Menurut Priyadi, masih banyak masyarakat pedesaan di Purbalingga dan Banyumas yang memegang teguh kepercayaan terhadap tabu. Tabu nikah yang ada di dua tempat ini menurutnya sering kali memunculkan konflik sehingga mereka takut untuk melanggar tabu nikah (Priyadi, 2006:166).

Kelima, tabu melahirkan. Wanita hamil juga punya banyak pantangan atau tabu yang tidak boleh dilanggar kalau tidak ingin terjadi apaapa dengan kehamilannya atau pada saat melahirkannya. Misalnya, wong meteng mah ora olih ngumbah sikil kalawan banyu bekas kumbahan, matak ngalahirakene gati' 'perempuan hamil tidak boleh nyuci kaki dengan air bekas cucian, takut nanti melahirkannya susah'; wong meteng ora olih ngagulibedaken anduk atawa kain ning gulu, matak bayine kagulibet ari-ari pas lahirane 'orang hamil tidak boleh mengikatkan kain di leher, takut nanti bayinya terbelit tali puser'; dan sebagainya.
Keenam, tabu perempuan lainnya. Wanita melahirkan atau pasca melahirkan sering juga aktivitasnya dibatasi oleh tabu-tabu yang tidak boleh dilanggar. Misalnya, wong entas ngalahiraken mah ora olih mangan gedang, matak metu kontol 'perempuan yang baru melahirkan tidak boleh makan pisang, takut keluar penis'; wong wadon sing entas lahiran ulih pirang-pirang dina ora ulih dodok slonjor ning arep umah soale setan ngintili 'perempuan melahirkan selama beberapa hari tidak boleh duduk selonjoran di depan rumah, takut diikuti setan'; dan sebagainya.

Banyak tabu di Banten yang berlaku untuk perempuan semua usia, dari mulai anak-anak, gadis, ibu-ibu hamil, maupun perempuanperempuan lain pada umumnya. Di antara tabutabu yang sampai sekarang masih bertahan dan masih diingat oleh perempuan Banten adalah wong wadon mah lamun nyanyapu aja setengahsetengah, matak olih lakine brewokan 'perempuan tidak boleh menyapu setengah-setengah, nantinya dapat suami berewokan'; awewe mah ulah mam dina mangkok, bisi jauh jodoh 'perempuan tidak boleh makan di mangkok, nanti jodohnya jauh'; dan lain sebagainya.

\section{FUNGSI TABU BAGI PEREMPUAN BANTEN}

Setidak-tidaknya ada empat fungsi dan peran tabu bagi kehidupan sosial keagamaan masyarakat Banten. Tabu berfungss untuk menjaga moral dan perilaku. Sebagian besar tabu mengandung pesanpesan dan nilai-nilai moral yang harus dijunjung tinggi oleh masyarakat setempat. Laranganlarangan tabu secara implisit mengandung etika kesopanan dan moral bagaimana manusia harus bertingkah laku dan bersikap dalam kehidupan sehari-hari sesuai dengan adat dan norma yang berlaku dalam budaya masyarakat kita. Tabu-tabu seperti wong wadon mah aja ilok metu bengi, matak digawa wewe 'perempuan tidak boleh keluar malam-malam, takut di bawa hantu'; wong wadon mah aja ilok seserit bengi-bengi, matak nyugihaken tetangga 'jangan suka nyisir rambut malam-malam, nanti yang kaya tentangganya'; dan lain sebagainya merupakan bentuk-bentuk larangan yang mengandung unsur-unsur etika bagaimana bersikap dan berperilaku dalam kehidupan seharihari.

Kedua, tabu dapat memperkuat hubungan 
emosional antara ibu dan anak, antar suami dan istri dan antar keluarga. Bentuk perhatian seorang ibu terhadap anak, suami terhadap istri, satu anggota keluarga terhadap anggota keluarganya dapat dilakukan dengan berbagai cara. Salah satunya adalah melalui tabu-tabu ini. Ada makna dan simbol kasih sayang dan cinta dalam tradisi tabu perempuan. Seorang ibu yang tidak mau melihat anaknya (terutama anak perempuannya yang sedang hamil) mendapat celaka karena melanggar tabu, pasti akan menghalangi atau paling tidak memberitahu bahwa hal ini dilarang, hal itu tabu, dan lain sebagainya, agar anaknya selamat. Apa yang dilakukan oleh seorang ibu tersebut merupakan bentuk kasih sayang dan perhatian yang tulus seorang ibu. Seorang anak akan merasa dibutuhkan dan disayangi oleh ibunya. Hal ini menjadi sugesti positif bagi pribadi anak, dan sebaliknya anak akan memberikan yang terbaik buat ibunya. Dengan adanya kesadaran akan bentuk perhatian dan kasih sayang melalui kalimat-kalimat tabu tersebut, bukan hanya tabu saja yang kemudian dapat terus terpelihara di masyarakat, tetetapi juga hubungan emosional atara ibu dan anak serta hubungan antarkeluarga juga dapat lebih kuat dan lebih dekat.

Ketiga, tabu berfungsi menjaga dan melindungi perempuan dan anak-anak. Berbagai tabu yang tersebar di Banten banyak yang berkaitan dengan perempuan, khususnya perempuan hamil dan calon bayinya. Pantangan dan larangan yang diberlakukan bagi ibu-ibu hamil ini berfungsi untuk melindungi perempuan dan anak-anak. Tabu-tabu seperti wong meteng lamun entas nyekel apa bae aja ilok kekusut ning awak dewek, matak pada biru silit si bayine; wong meteng lamun lagi ngungumbah, banyu bekas kukumbahane aja ilok disiram ning sikil dewek, matak sikile bengkak; wong meteng aja ilok ngarendem kukumbahan, matak ngalahirakene gati; dan sebagainya semuanya berkaitan dengan bagaimana seorang perempuan hamil tabu melakukan aktivitasaktivitas tertentu karena akan berakibat buruk atau berdampak negatif, baik bagi dirinya maupun bagi calon bayinya. Dari tabu-tabu tersebut, jelas bahwa banyak tabu yang diberlakukan bagi perempuan dan tabu-tabu ini sebagian besar mengandung nilai dan makna bahwa perempuan adalah mahluk lemah yang betul-betul membutuhkan perlindungan ekstra. Dengan demikian, tabu hadir sebagai bentuk perlindungan bagi kaum perempuan dan bayi atau anaknya yang dianggap sebagai makhluk yang lemah.

Keempat, tabu juga berfungsi untuk menumbuhkan rasa sayang dan cinta kepada sesama manusia maupun kepada makhluk Tuhan yang lain, termasuk kepada binatang. Sebagian tabu yang masih bertahan di masyarakat Banten mengandung nilai kasih sayang yang tersirat di dalamnya. Misalnya, seorang perempuan yang sedang hamil dilarang membunuh atau melukai binatang dikhawatirkan anaknya akan lahir cacat. Jika tabu semacam ini dianalisis, tampak bahwa betapa si pembuat tabu juga memperhatikan nilai moral dan nilai kasih sayang bukan hanya ditujukan kepada ibu untuk anaknya, tetetapi juga kasih sayang kepada makhluk lain. Makna yang tersirat di dalam tabu tersebut menyimbolkan bahwa manusia juga tidak boleh bertindak semenamena dan berbuat jahat kepada binatang. Mengapa tabu-tabu semacam ini hanya ditujukan kepada ibu-ibu hamil? Agaknya, hanya ibu-ibu hamillah yang kemungkinan besar tidak akan melanggar tabu itu karena kondisi emosional dan psikologis mereka. Seorang ibu hamil akan melakukan apa pun demi keselamatan bayinya, apalagi kalau hanya sekadar menghindari tabu.

\section{SIMPULAN}

Menjadi modern bukan berarti menghilangkan semua hal mistis yang ada dalam pemikiran manusia. Barangkali sebagian besar ragam tabu atau sesuatu yang disakralkan dan dimitoskan sudah hilang dan ditinggalkan oleh pengikutnya karena perubahan zaman dan proses modernisasi. Namun, secara kualitas pikiran-pikiran serta ide-ide tentang tabu dan sakralitas akan terus ada walaupun aplikasinya serta kepercayaan terhadapnya sudah tidak sebanyak dan sekuat pada zaman prasejarah.

Keberadaan tabu perempuan pada masyarakat Banten, meskipun mereka akui sangat tidak logis dan tidak rasional, namun melanggar apa yang ditabukan oleh budaya mereka menjadi suatu hal yang sangat mereka hindari. Karena apa yang ada dalam pikiran sebagian masyarakat Banten, tabu, meskipun tidak diketahui asal-usulnya, dan bukan berasal dari agama, tetetapi mereka yakin 
bahwa tabu-tabu itu mengandung "hikmah" karena merupakan warisan dari leluhur mereka sehingga melanggar tabu bagi mereka sama saja dengan menantang kekuatan magi yang meliputi tabu.

Beragam tabu yang ada pada masyarakat Banten, khususnya yang berkaitan dengan tabu perempuan Banten, jika dianalisis maknanya baik secara tekstual maupun kontekstual memilikiki fungsi dan makna sebagai bentuk penjagaan moral dan perilaku, memperkuat hubungan emosional, bentuk perlindungan, sampai simbol kasih sayang dan cinta. Tabu memiliki multiinterpretasi yang kemungkinan akan terus bertahan sampai beberapa generasi berikutnya di Banten.

\section{DAFTAR RUJUKAN}

Agus, Bustanuddin. (2009). Agama dalam kehidupan Manusia. Pengantar Antropologi Agama. Yogyakarta: LKiS.

Bowen, John Richard. (1998). Religions in Practice. An Approach to the Anthropology of Religion. Washington: Allyn \& Bacon.

Buckley, T and Gottlieb, A. (eds.).(1988). Blood Magic: The Anthropology of Menstruation. Berkeley: University of California Press.

Frazer, S.J. George. (1935). The Golden Bough, Vol.3., of Tabu and the Perils of the Soul. New York: Macmillan. . (1993). The Golden Bough: A Study in Magic and Religion. New York: Hertfordshire.

Freud, Sigmeund. (1950). Totem and Taboo: Resemblances between the Psychic Lives of Savages and Neurotics. New York: Moffart, Yard and Company.

Gamman, Lorraine dan Margaret Marshment. (eds.). (2009). Tatapan Perempuan: Perempuan sebagai Penonton Budaya Populer. Terj. Betharie Anissa Ismayasari. Yogyakarta: Jalasutra.

Hamilton, Malcolm. (2001). The Sociology of Religion. Theoritical and Comparative Perspectives, $2^{\text {nd }}$ ed. New York:Routledge.

Handayani, Trisakti dan Sugiarti. (2002). Konsep dan Teknik Penelitian Gender. Malang: UMM Press.

Hinnells, John R. (1984). The Dictionary of Religious. London: Penguin Books Ltd.

Humaeni, Ayatullah. (2010). Mitos dan Tabu dalam Budaya Banten. (Laporan Penelitian). IAIN "SMH" Banten, Banten

Laws, S. (1990).Issues of Blood: The Politics of
Menstruation. London: Macmillan.

Malinowski, Bronislaw. (1955). Magic, Science and Religion and Other Essays. New York: Doubleday Anchor Books.

Priyadi, Sugeng. (2006). Konflik Sosial Tabu Nikah pada masyarakat Perdesaan di Purbalingga dan Banyumas. JurnalHumaniora, Vol. 18, No.2, 165-177.

Ratna, Nyoman Kutha. (2010). Metodologi Penelitian Kajian Budaya dan Ilmu Sosial Humaniora pada Umumnya. Yogyakarta: Pustaka Pelajar.

Rodrigues, Hillary and John S. Harding. (2009). Introduction to the Study of Religion. London and New York: Routledge.

Stake, Robert E. (2009). Studi Kasus.dalam Norman K.Denzin dan Yvonna S.Lincoln. (eds.). Handbook of Qualitative Research. Yogyakarta: Pustaka Pelajar.

Syam, Nur. (2010). Agama Pelacur. Dramaturgi Transendental. Yogyakarta: LKiS.

Treneman, Ann. (2009). Mengeruk Keuntungan dari Kutukan: Iklan dan Pelbagai Hal yang dianggap Tabu ketika Menstruasi. Dalam Gamman, Lorraine dan Margaret Marshment. (ed.). Tatapan Perempuan: Perempuan sebagai Penonton Budaya Populer. Terj. Betharie Anissa Ismayasari. Yogyakarta: Jalasutra.

Turner, Bryan S. (2003). Agama dan Teori Sosial. Rangka-Pikir Sosiologi dalam Membaca Eksistensi Tuhan di antara Gelegar IdeologiIdeologi Kontemporer. Terj. Inyiak Ridwan Muzir. Yogyakarta: IRCiSoD.

Webster, Hutton. (1942). Taboo. A Sociological Study. California: Stanford University Press.

Weber, Max. (1964). The Sociology of Religion. Transl. Ephraim Fischoff. Boston: Beacon Press.

\section{SUMBER DATA}

Wawancara dengan Ibu SL, Cipare Ranjeng, Serang, Banten, 24 Oktober 2011

Wawancara dengan Ibu Hj.Slk, Barugbug Ciomas Serang Banten, 15 September 2011.

Wawanca dengan Ibu Adl, seorang dukun beranak/ dukun bayi, 61 thn, di Kp.Sawah, Ds. Ciomas, Serang Banten, 30 Agustus 2014.

Wawancara dengan Ibu Fzh, 22 thn, seorang mahasiswa IAIN, di Kota Serang Banten, 1 September 2014

Wawancara dengan Ibu Yyh, 33 thn, seorang PNS, di Kota Serang Banten, 1 September 2014

Wawancara dengan Ibu Een, 45 thn, Ibu Rumah Tangga, di Kota Serang Banten, 29 Agustus 2014. 